\title{
Chemical and Microscopy Characterization of Trans-Endodontic Implants
}

\section{Caracterización química y microscópica de implantes trans-endodónticos}

Alexis Larios-Cervantes DDS ${ }^{1}$; Luis Aguilera-Galaviz DDS, MSc, PhD2;

Héctor Flores Reyes DDS, MSc, PhD3; Víctor Hugo Baltazar Hernández DDS, MSc, PhD4; Crescencio Rodríguez DDS ${ }^{5}$; César Gaitán-Fonseca DDS, MSc, PhD²

1. Estudiante de la Maestría en Ciencias Biomédicas, Área de Ciencias de la Salud,

Universidad Autónoma de Zacatecas "Francisco García Salinas", México.

2. Docente-Investigador, Maestría en Ciencias Biomédicas, Área de Ciencias de la Salud, Universidad Autónoma de Zacatecas "Francisco García Salinas", México.

3. Docente-Investigador, Laboratorio de Ciencias Básicas, Facultad de Estomatología, Universidad Autónoma de San Luis Potosí, México.

4. Docente-Investigador, Unidad Académica de Ingeniería I, Universidad Autónoma de Zacatecas "Francisco García Salinas", México.

5. Estudiante de la Maestría en Ciencia e Ingeniería de los Materiales, Universidad Autónoma de Zacatecas "Francisco García Salinas", México.

Correspondence to: Dr. César Gaitán-Fonseca - cgaitan@uaz.edu.mx

D0I: https://doi.org/10.15517/ijds.v0i0.30282

\section{ABSTRACT}

Trans-endodontic implants are an artificial extension through root apex anchored in periradicular bone tissue. The aim is to improve the crown-root ratio and to provide stability to dental organ present. Zirconium oxide ( $\left.\mathrm{ZrO}_{2}\right)$ is a material of great technological importance, having good natural color, high strength, high toughness, high chemical stability, does not suffer any corrosion, chemical and microbial resistance and excellent esthetic properties. Objective: The aim of this study was to evaluate chemical and microscopy of surface conditions of $\mathrm{ZrO}_{2}$ trans-endodontic implant. Materials and Methods: A blocks of $\mathrm{ZrO}_{2}$ were manufactured for produce trans-endodontic implants and divided in two groups: monoclinic and tetragonal phase. They were evaluated using Scanning Electroning Microscope (SEM), EnergyDispersive X-ray Spectroscopy (EDS), and Atomic Force Microscope (AFM) and Vickers Micro hardness. Results: The Monoclinic phase through AFM analysis showed roughness $R a=0.320 \mu m$, whereas in the Tetragonal phase was $0.126 \mu \mathrm{m}, \mathrm{SEM} / \mathrm{EDX}$ indicated that the phases are not properly uniform and the addition of the Yttrium to favor the stabilization of the Tetragonal phase. The Vickers hardness analysis showed a value of $1500 \mathrm{HV}$. Conclusion: The characterization of the surface of trans-endodontic zirconium oxide implants provides a guideline to know the surface characteristics of the material, since a greater roughness on the surface of the implant will favor the 0sseo-integration capacity. 


\section{KEYWORDS}

Trans-endodontic implants; Zirconium oxide; Scanning electron microscope (SEM); Energy-dispersive X-ray spectroscopy (EDS); Atomic force microscope (AFM); Vickers hardness.

\section{RESUMEN}

Los implantes trans-endodónticos son una extensión artificial a través del ápice radicular anclado en el tejido óseo periradicular. El objetivo es mejorar la relación corona-raíz y proporcionar estabilidad al órgano dental presente. El óxido de zirconio ( $\left.\mathrm{ZrO}_{2}\right)$ es un material de gran importancia tecnológica, con buen color natural, alta resistencia, alta tenacidad, alta estabilidad química, no sufre corrosión, resistencia química y microbiana y excelentes propiedades estéticas. Objetivo: El objetivo de este estudio fue evaluar las condiciones superficiales de $\mathrm{ZrO} 2$ para su aplicación clínica a los implantes transendodónticos. Materiales y Métodos: se trituraron bloques de $\mathrm{ZrO} 2$ en implantes trans-endodónticos y se dividieron en: monoclínico y tetragonal. Luego se evaluaron mediante microscopía electrónica de barrido (SEM), espectroscopia de rayos $X$ de energía dispersiva (EDS) y microscopio de fuerza atómica (AFM) y microdureza vickers. Resultados: La fase monoclínica a través del análisis AFM presenta $\mathrm{Ra}=$ $0.320 \mu \mathrm{m}$, mientras que en la fase Tetragonal es $0.126 \mu \mathrm{m}$, SEM / EDS muestra que las fases no son adecuadamente uniformes y la adición del Ytrio para favorecer la estabilización de la fase tetragonal. El análisis de microdureza mostro un valor de 1500HV. Conclusión: La caracterización de la superficie de los implantes trans-endodónticos de óxido de zirconio, brinda una pauta para conocer las características superficiales del material, ya que al haber una mayor rugosidad en la superficie del implante se verá favorecida la capacidad de oseointegración.

\section{PALABRAS CLAVE}

Implantes trans-endodónticos; Óxido de zirconio; Microscopio electrónico de barrido (SEM); Espectroscopia de rayos X de energía dispersiva (EDS); Microscopio de Fuerza Atómica (AFM); Microdureza de vickers.

\section{INTRODUCTION}

Trans-Endodontic implants are an artificial extension through the root apex anchored in the periradicular bone tissue with the aim of improving the crown-root ratio and provide stability to the dental organ present (1-3).

Some studies have looked into the development of trans-endodontic implants. The first case was reported by Stock \& Stock (1943), it was a metallic element (Vitallium alloy), disposed along the root canal, anchoring into the periradicular bone, the aim of this therapy was to prolong three crown- root ratio (4). Subsequently, Chercheve (1962) developed a titanium implant, which consisted of a helical screw with a long neck that emerged from the mucous membrane. Scialom (1962) made tantalum needles that were placed in the bone in three different directions and the needle projections were joined with acrylic or amalgam, to create a stump, like a tooth (1).

Orlay in Europe was the first to recommend endodontic implants; in the US, Frank (1965-1975) recognized to standardize the technique, developing the appropriate instruments and a procedure predictable (5). Feldman \& Feldman defended the 
idea of use endodontic implants as a way to stabilize and retain the teeth, and then the anatomical structures were considered unstable (6).

The different materials along with implementation of trans-endodontic implants mark a guideline for development of materials that improve upon features already established such as Osseointegration, biocompatibility, toxicity, durability and functionality.

Zirconium oxide ( $\left.\mathrm{ZrO}_{2}\right)$ is a ceramic material that has been used in recent decades, in various areas including biomedicine since 1969 (7). In dentistry, $\mathrm{ZrO}_{2}$ is a material of great technological importance, having natural color, high strength, high toughness, high chemical stability, avoid corrosion and microbial grown resistance (8).

$\mathrm{ZrO}_{2}$ can take three different crystal structures: monoclinic, tetragonal $\left(1170^{\circ} \mathrm{C}\right)$, and cubic $\left(2370^{\circ} \mathrm{C}\right)(9)$, the monoclinic phase is fragile at room temperature, and therefore requires stabilization to prevent the transformation of tetragonal phase to monoclinic $(10,11)$, a stress-induced transformation toughening mechanism that improves mechanical strength of zirconia rendering it more suitable as a dental implant material (12).

Yttrium $\left(\mathrm{Y}_{2} \mathrm{O}_{3}\right)$ is used as a general stabilizer for maintaining the tetragonal phase of $\mathrm{ZrO}_{2}(13$, 14), $Y_{2} \mathrm{O}_{3}$ Tetragonal zirconia polycrystals (Y-TZP) are biocompatible (15) and exhibit the best combination of strength and toughness in singlephase oxide ceramics. This material exhibits a very high flexural strength (900 to $1200 \mathrm{MPa}$ ), a notable fracture toughness (KIC 7 to $10 \mathrm{MPa} \cdot \mathrm{m} 1 / 2)$ and a Young's modulus of $210 \mathrm{GPa}$ (16). Roughness is one of the key parameters for successful Osseointegration of dental implants (17), successful Osseointegration depends on numerous surface properties such as topography and chemistry (18).

Surface modifications may have a positive effect on bone apposition and bone in-growth, but also could facilitate water penetration into the bulk and/or lead to a modification of the stability of the tetragonal phase under humid conditions (19). Hardness is a characteristic of a material, not a fundamental physical property. It is defined as the resistance to indentation, and is determined by measuring the permanent depth of the indentation. More simply, when a fixed force (load) and a given indentation are used, the smaller the indentation, the harder the material (20). The hardness value of the indentation is obtained by measuring the depth or the area of the indentation.

The aim of this study was to evaluate chemical and microscopic surface characterization of $\mathrm{ZrO} 2$ trans-endodontic implants.

\section{MATERIAL AND METHODS}

\section{MATERIAL}

A Zirconium oxide blocks ( $\left.\mathrm{ZrO}_{2}\right)$, were used provided byZirkonzahn-Italy, a manual milling machine (Zirkonzahn), a sintering furnace (Zirkonofen), and deionized water, trans-endodontic implant molds, 3D printer, acrylic and monomer.

\section{TRANS-ENDODONTIC IMPLANT FABRICATION}

These implants were made with the following specifications: this type of implant was considered according to the conditions of the dental organ and the anatomical characteristics in which the trans-endodontic implant will be used, a pattern is prepared in a software with the pre-established measures, Later the mold is obtained in acrylic by a 3D printer da Vinci 1.0 AiO (XYZPRINT) with which the milling is carried out indirectly with the manual milling machine for zirconia (Zirkonzahn), using monoclinic blocks of zirconium oxide $(4.2 \mathrm{~cm}$ $\times 2.2 \mathrm{~cm} \times 2.4 \mathrm{~cm})$.

Four blocks of $\mathrm{ZrO} 2$ were used to manufacture trans-endodontic implants and then two of them 
were sintered at $1170^{\circ} \mathrm{C}$ in a sintering furnace for 12 hours to convert at tetragonal phase, and two were kept in the original phase (monoclinic), (Figure 1).

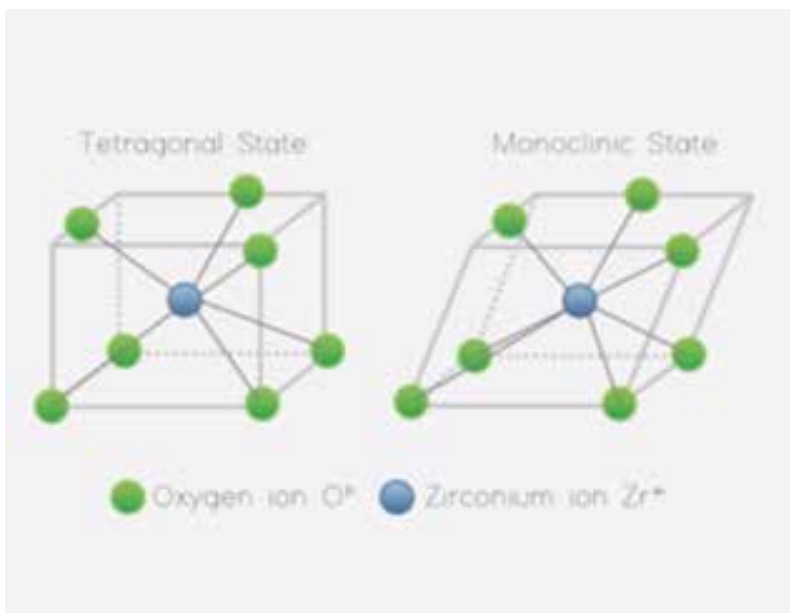

Figure 1. Zirconium oxide phase transformation. Phase change of the ions of zirconium oxide and oxygen in monoclinic phase, and subsequent to the sintered the tetragonal phase.

The zirconium Oxide blocks were provided by the Laboratory in Dental Materials Research, UniversidadAutonomaAguascalientes, the endodontic implants were manufactured in Zirkonzahn system.

\section{AFM ANALYSIS}

To evaluate topography and compare the differences between implants fabricated with monoclinic zirconium oxide and tetragonal zirconium oxide studied via Atomic Force Microscope (Bruker Dimension Edge), were carry out, characterized by a three-dimensional topographic technique with high atomic resolution. Monitoring surface topographies in tapping mode, at room temperature $\left(25^{\circ} \mathrm{C}\right)$ using a tip (SMC-PIT model), at scan rate of $0.3 \mathrm{~Hz}$ and scan size of $20 \times 20 \mu \mathrm{m} 2$. The images obtained were processed with Nanoscope Analysis v1.40 software.

\section{SEM ANALYSIS}

Implants microstructural aspect was evaluated using a Scanning Electron Microscope (SEM). Surface analysis and energy-dispersive
X-ray spectroscopy (EDS) was performed for identification of elemental atomic species in both implants. SEM micrographs were taken with JEOL JSM-820 (USA) Scanning Electron Microscope and processed with NanoScope software (Bruker).

\section{VICKERS MICRO HARDNESS}

A sample was prepared in the form of a disc of $\emptyset 5 \mathrm{~mm}$ and $5 \mathrm{~mm}$ (height) of zirconium oxide in tetragonal phase. Ten indentations were made on surface and micrograph of each one was attached. The separation between each indentation was $0.25 \mathrm{~mm}(250 \mu \mathrm{m})$.

\section{RESULTS}

\section{IMPLANT FABRICATION}

The advantages of the use of transendodontic implants of zirconium oxide compared to conventional implants (Figure 2), are that it tends to preserve the natural teeth, since the implant is placed through the root canal and with this a natural epithelial junction of the Same dental organ with periodontal structures, the bolt has the function of prolonging the root length and decrease the abnormal tooth mobility, in addition to that this material does not present corrosion.

After the use of the acrylic mold of the transendodontic implant, and zirconium oxide milling with the milling and sintering, a trans-endodontic implant was obtained, $2 \mathrm{~mm}$ in diameter and 18 $\mathrm{mm}$ in length, with which the following tests were carried out for the characterization.

\section{AFM ANALYSIS}

In this analysis was evaluated absolute roughness of $\mathrm{ZrO} 2$ during the manufacture process, which showed a $0.315 \mu \mathrm{m}$ value, in monocyclic phase, where the surface has an increased roughness in raw material. $\mathrm{ZrO}_{2}$ after sintered 
process was obtained a $.126 \mu \mathrm{m}$ roughness in tetragonal phase (Figure 3). As we see in this analysis $\mathrm{ZrO}_{2}$ in monoclinic phase shows a better roughness but as it was mentioned this phase cannot be used for clinical applications.
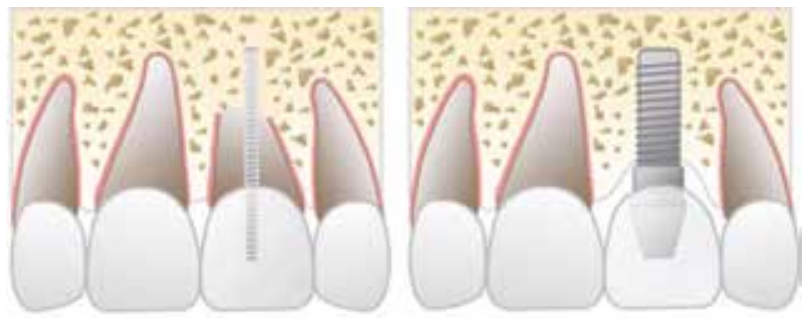

Figure 2. Advantages of transendodontic implants of zirconium oxide compared to conventional implants. preserve the natural teeth, since the implant is placed through the root canal and with this a natural epithelial junction of the Same dental organ with periodontal structures, the bolt has the function of prolonging the root length and decrease the abnormal tooth mobility, in addition to that this material does not present corrosion.
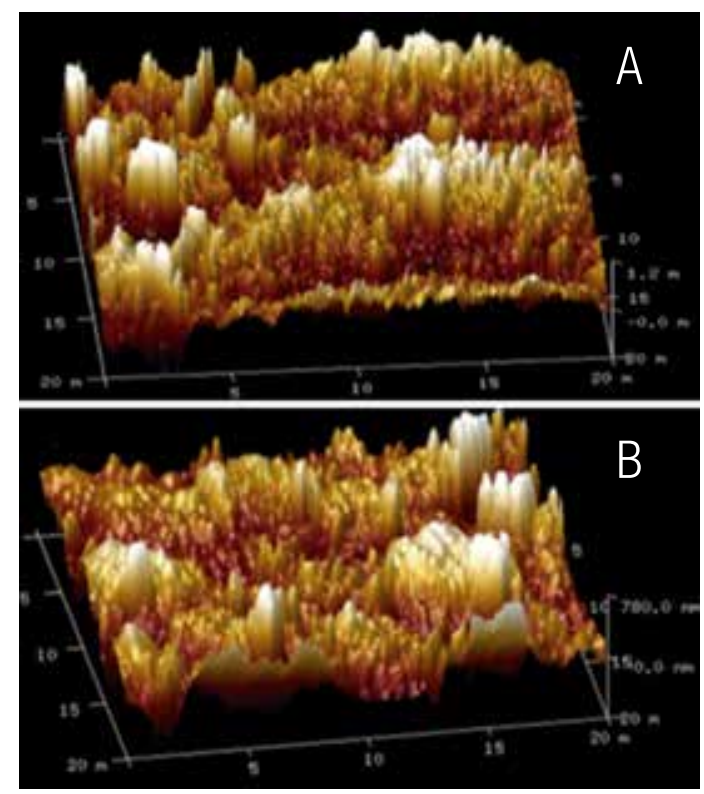

Figure 3: $\mathrm{ZrO}_{2}$ Absolute Roughness (Ra): a) Monoclinic phase showed a higher topographic roughness ( $\mathrm{Ra}$. .320 $\mu \mathrm{m})$ at natural state. b) Tetragonal phase showed a lower roughness ( $\mathrm{Ra} .126 \mu \mathrm{m})$ after sintered process. The monoclinic phase has a greater roughness but cannot be used as a trans-endodontic implant.

\section{SEM ANALYSIS}

To determine the morphology and size of the particles were observed using a Scanning Electron Microscope which shows that the phases are not properly uniform, for example in figure $4 \mathrm{a}$, corresponding to the Monoclinic phase, a relief is observed in which the surface is smooth and with few small and scattered particles, however the Tetragonal phase (Figure 4b) spheres of an average size and $2 \mu \mathrm{m}$ are observed.

In addition, the EDS spectra were obtained in these energy spectra, characteristic peaks of the elements present, such as Zirconium, Calcium (Ca), Oxygen (Y), Yttrium (Y), Carbon (C), Aluminum (Al), Chlorine $(\mathrm{Cl})$, and Potassium $(\mathrm{K})$, in the monoclinic phase (Figure 4c); Similarly, after the sintering process, the characteristic peaks of the tetragonal phase of $\mathrm{ZrO}_{2}$ are observed, thus confirming the presence of Ytrio to favor the stabilization of the Tetragonal phase, (Figure 4d).

\section{VICKERS HARDNESS}

This method consisted in introducing the test material with a diamond indenter in the form of a pyramid with a square base and an angle of 136 degrees between opposing faces subjected to a test force of between $1 \mathrm{~g}$ and $100 \mathrm{kgf}$. The full charge was applied for 15 seconds.

The two diagonals of the indentation remaining on the surface of the material after the removal of the charge were measured using a microscope and its average (Fig. 5). The area of the inclined surfaces of the indentation was calculated which was $1500 \mathrm{HV}$. 


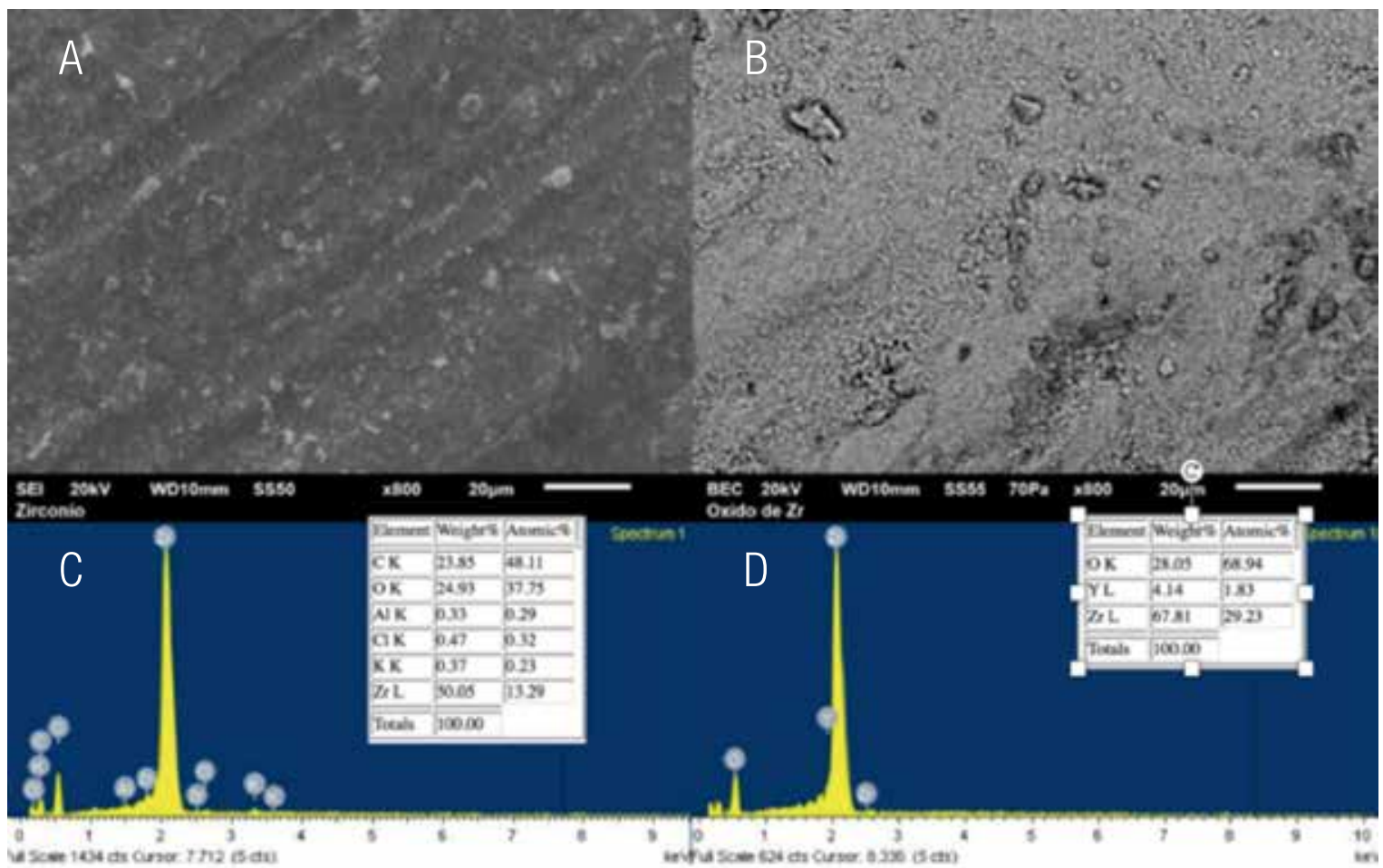

Figure 4. SEM/EDS analysis. SEM a) SEM image of $\mathrm{ZrO}_{2}$ in monoclinic phase, $\mathrm{x} 800$ objective, b)SEM image of $\mathrm{ZrO}_{2}$ in tetragonal phase, final process after sintered treament at $1170^{\circ} \mathrm{C}$. C) EDS analysis showed the compounds of $\mathrm{ZrO}_{2}$ in monoclinic phase. d) EDS final compounds of $\mathrm{ZrO}_{2}$.

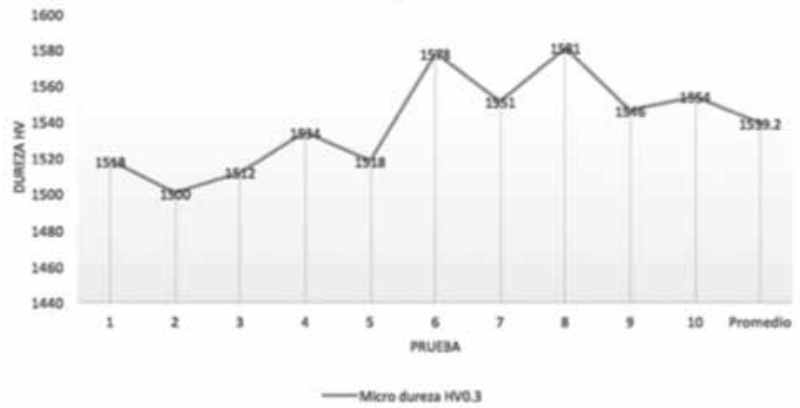

Figure 5. Vickers $\mathrm{ZrO}_{2}$ tetragonal microhardness: load: $2.942 \mathrm{~N}$ $(300 \mathrm{gr})$ for 15 seconds, 10 indentations. The result of the sum of the indentations was $1500 \mathrm{HV}$. 
DISCUSSION

Endodontic implants have the aim of improving the crown-root ratio and providing stability to tooth affected (1-3). This technique has been implemented due to the innovative materials that have emerged for biomedical and dental applications; from the use of alloys such as cobaltchromium, chromium-cobalt-molybdenum and titanium, to ceramics such as zirconia, which we can attribute properties such as its high potential for Osseointegration, translucency and white color that mimics natural teeth; It is radiopaque and can easily be visualized on X-ray (21). Also, the use of endodontic implants gives us greater permanence of the tooth in the mouth. Bacterial colonization is lower compared to titanium as the plaque formation of the implant surface leading to good healing and treatment a success is reduced. Some studies have reported that zirconium oxide has more biocompatibility compared to titanium, because the latter producing corrosion products in the implant site (22).

Several authors that have studied zirconia properties states that it biocompatible and osseintegrable material, however aging of material, in search of more lasting Osseo integration and life remains an object of study.

Clarisse Shannon and Col. (19) mentions that should be tested for strength and durability to evaluate the microstructural changes in each design made with zirconia, since the time of life may depend on surface preparation. As previous studies showed that bone-to-implant surface contact was improved by increasing surface roughness (13), in this study AFM analysis shows that roughness is an important aspect for the success implant (23), this is because the roughness provides a porous surface in which the formation of bone will have a greater retention which favors the process of Osseointegration, however an excess of roughness can cause the opposite effect due to the transformation of phases that undergoes oxidation of zirconium, in addition to the aging process of the material $(24,25)$, because when encountered in a humid atmosphere, the temperature and humidity play an important role in the stability and hardness of the implant, and being a material subjected to loads and occlusal forces, the hardness is an essential aspect as well as mechanical resistance and toughness (26).

Due to the martensitic properties of zirconium oxide, SEM / EDS analysis is essential to evaluate phase transformation, since the predetermined phase diagram shows that to maintain the tetragonal phase of $\mathrm{ZrO}_{2}$, a dopant is needed which in this case was used Yttrium, since it shows characteristics of toughness, mechanical resistance and hardness greater than other dopants besides being a biocompatible element, the grain size of these polycrystals conjugates with the aforementioned elements such as the aging and the resistance to fracture (27), which according to the SEM analysis is about $2 \mu \mathrm{m}$, we could say that it is a size adequate for the need of the implant, on the other hand the atomic percentage and the weight of the materials indicated by the EDS analysis, confirms the presence of elements after the sintering process, so that in the tetragonal phase we find the characteristic elements of phase, yttrium, zirconium and oxygen.

\section{CONCLUSION}

The surface characterization of transendodontic zirconium oxide implants provides a guideline for the superficial characteristics of the material, which are of great importance in order to obtain more satisfactory results, since there is a greater roughness on the surface of the implant the Osseointegration capacity will be favored.

On the other hand, the roughness, morphology and size of the crystals (particles) of the material provide, as well as their components 
in both studied phases, an approximation of the hardness of the implant, besides it can resemble or give us an idea of the change of phase of transformation due to the aging process.

\section{REFERENCES}

1. Larios A. Gaitan C. Aguilera L. Aceves M. Diseño, fabricación y evaluación clínica de implantes trans-endodónticos de Óxido de Zirconio. Revista Iberoamericana de Ciencias. 2016; ISSN 2334-2501.

2. Yadav R. Tikku A. Chandra A. Wadhwani K. Singh M. Endodontic implants. Natl J Surg.2014; 5,70-3.

3. Santos A. Cava C. Robello J. Implante transendodontico de Cromo-Cobalto. 2004; KIRU.

4. Cava C. Extirpación de canino retenido y estabilización dental mediante implantes endodónticos. Kiru. 2009; 6 (1), 46-52.

5. Weine FS. Survival of the endodontic endosseous implant. J Endod. 1993; 19,524-8.

6. Mittal S. Kumar T. Aggarwal V. Bansal R. Kaur D. Endodontic stabilizers for treating mid root fractures. 20015; 200.78.241.250.

7. Velázquez R. Vaquero C. Torres D. Jiménez M. Gutiérrez J. Mechanical resistance of zirconium implant abutments: A review of the literatura. Med Oral Patol Oral Cir Bucal. Mar 1 2012;17 (2): e246-50.

8. A. K. Singh and Umesh T. Nakate. Microwave Synthesis, Characterization, and Photoluminescence Properties of Nanocrystalline Zirconia. The Scientific World Journal Volume, 2014; Article ID 349457.

9. Y. D. Belo, Q. N. Sonza, M. Borba, A. D. BonaZircônia tetragonal estabilizada por ítria: comportamentomecânico, adesãoe longevidade clínica. Cerâmica 2013; 59, 633-639.

10. Oleshko V. Howe J. Shukla S. Seal S. HighResolution and Analytical TEM Investigation of Metaestable-Tetragonal Phase Stabilization in Undoped Nanocrystalline Zirconia. Journal of Nanoscience and Nanotechnology. 2004; Vol. 4, No. 7.

11. Joo J. Yu T. Woon Y. Min H. Wu F. Zhang J. Hyeon T. Multigram Scale Synthesis and Characterization of Monodisperse Tetragonal Zirconia Nanocrystals. J. AM. CHEM. SOC., 2003; 125, 6553-6557.

12. Hyung-Tae K, Jung-Suk H, Jae-Ho Y. JaiBong L. Sung-Hun K. The effect of low temperature aging on the mechanical property \& phase stability of Y-TZP ceramics. J Adv Prosthodont 2009; 1: 113-7.

13. Young-Dan Cho. Ji-Cheol Shin. Hye-Lee Kim. Myagmar Gerelmaa. Comparison of the Osteogenic Potential of Titanium and Modified Zirconia-Based Bioceramics. Int. J. Mol. Sci., 2014; 15, 4442-4452; doi:10.3390/ ijms 15034442 .

14. Gaurav P. Jayaswal, S. P. Dange, A. N. Khalikar. Bioceramic in Dental Implants: A Review Journal of Indian Prosthodontic Society (March). 2010; 10: 8-12.

15. Thomas A. Shidar S. Aghyarian S. WatkinsCurry P. Corrosion behavior of zirconia in acidulated phosphate fluoride. J Appl Oral Sci. 2016; 24 (1): 52-60.

16. Sevilla P. Sandino C. Arciniegas M. MartínezGomis J. Peraire M. Gil F. Evaluating mechanical properties and degradation of YTZP dental implants. "ELSEVIER" Materials Science and Engineering C", 2010; 30 14-19.

17. Flamant Q. Stanciuc A. Pavailler H. Sprecher C. Roughness gradients on zirconia for rapid screening of cell-surface interactions: Fabrication, characterization and application. Journal of Biomedical Materials Research A | Month 2016 Vol 00a, Issue 00.

18. Anil S., Anand P. S., Alghamdi H., Jansen J. A. Dental implant surface enhancement and osseointegration. Implant Dent-A Rapidly Evol Pract 2011. 83-108 p. 
19. Sanon C. Chevalier J. Douillard T. CattaniLorente. A new testing protocol for zirconia dental implants. "ELSEVIER, Dental materials" 31, 2015; 15-25.

20. Papia E. Jimbo R. Chrcanovic B. Andersson M. (2014). Surface structure and mechanical properties of impaction-modified Y-TZP. "Dental materials". 30, 808-816.

21. Science Associated Editors, L. L. C Instituciones de Educación Superior, "La labor investigadora e innovadora en México". [Dec. 2016]. Cheyenne, WY 82009. Chapter 2, 103 p. Disponible en http://www.scased. com/images/mx/978-1-944162-16-0.pdf

22. Apratim, A. Eachempati P. Krishnappa K. Singh V. Chhabra S. Shah S. Zirconia in dental implantology: A review. Journal of International Society of Preventive \& Community Dentistry. 2015; 5, 3, 147-156.

23. Vahabi S. Salman B. Javanmard A. Atomic Force Microscopy Application in Biological
Research: A Review Study. Iran J Med Sci June 2013; Vol 38 No 2.

24. Mota Y. Cotes C. Carvalho R. Machado J. Monoclinic phase transformation and mechanical durability of zirconia ceramic after fatigue and autoclave aging. "Journal of Biomedical Materials Research B: Applied Biomaterials". 2016; Vol 00b, Issue 00.

25. Papia E. Jimbo R. Chrcanovic B. Andersson M. Surface structure and mechanical properties of impaction-modified Y-TZP. "Dental materials", 2014; 30, 808-816.

26. Inokoshi M. Zhang F. De Munck J. Minakuchi S. Influence of sintering conditions on lowtemperature degradation of dental zirconia. Dental Materials. 30, 2014; 669-678.

27. Turb V. Tuncelli B. Sen D. Golle G. Evaluation of hardness and fracture toughness, coupled with microstructural analysis, of zirconia ceramics stored in environments with different $\mathrm{pH}$ values. Dental Materials Journal 2012; 31 (6): 891-902.

Attribution (BY-NC) - (BY) You must give appropriate credit, provide a link to the license, and indicate if changes were made. You may do so in any reasonable manner, but not in any way that suggest the licensor endorses you or your use. (NC) You may not use the material for commercial purposes. 